\title{
The Correlation between Physical Environmental Factors and Fatigue of The Workers at Ship Repair Workshop
}

\author{
Hubungan Faktor Lingkungan Fisik dengan Kelelahan pada Pekerja Workshop \\ Reparasi Kapal
}

\author{
Aulia Nur Pratiwi \\ PT Bukit Makmur Mandiri Utama \\ Jalan Pluit Selatan Raya, Pluit, Penjaringan, North Jakarta 14450, Indonesia
}

\begin{abstract}
Introduction: Fatigue is a body protection mechanism that prevents further detriments and can be recovered after having a sufficient amount of rest. The fatigue undergone by workers is one of the causes of occupational accidents. Fatigue can be triggered by several factors, such as physical environment factors, for instance, temperature and noise. This research aims to analyze the correlation between the temperature as well as noise and the work fatigue of the workers in the ship reparation workshop at PT X Surabaya. Methods: This research is descriptive observational research that applies the cross-sectional design. The sample of this research, the total population, consists of 32 people. The data is obtained through the temperature measurement by utilizing hygro-thermometer, noise intensity measurement by utilizing the sound level meter, and work fatigue level measurement by utilizing reaction timer. Those measurements are completed in two different locations, namely the office and workshop. The strength of the correlation among variables is scrutinized by applying Spearman correlation test with a focus on correlation coefficient value. Results: show that 14 people (43.8\%) do not suffer from any fatigue, 15 people (46.9\%) suffer from mild fatigue, 2 people $(6.2 \%)$ suffer from moderate fatigue, and 1 person (3.1\%) suffers from severe fatigue. The fatigue is mostly undergone by the workers exposed to the overheat temperature, which is as many as 18 people $(56.2 \%)$ and by those who are exposed to noise, which are 15 people (46.9\%). Conclusion: that there is a moderate correlation between temperature and fatigue $(p=0.519)$. Meanwhile, the noise $(p=0.688)$ has a strong correlation with the fatigue undergone by the workers in the ship reparation workshop at PT X Surabaya.
\end{abstract}

Keywords: noise, ship reparation, temperature, work fatigue

\begin{abstract}
ABSTRAK
Pendahuluan: Kelelahan merupakan suatu mekanisme perlindungan tubuh agar terhindar dari kerusakan lebih lanjut sehingga terjadi pemulihan setelah istirahat. Kelelahan pada pekerja merupakan salah satu penyebab terjadinya kecelakaan kerja. Kelelahan dapat disebabkan oleh berbagai faktor seperti lingkungan fisik yaitu temperatur dan kebisingan. Tujuan penelitian ini untuk menganalisis hubungan antara temperatur dan kebisingan dengan kelelahan pada pekerja area workshop reparasi kapal di PT. X Surabaya. Metode: Penelitian ini termasuk penelitian observasional deskriptif dengan desain cross sectional. Sampel pada penelitian adalah total populasi yaitu 32 orang. Data penelitian didapatkan dari pengukuran temperatur di tempat kerja dengan menggunakan alat hygro-thermometer, pengukuran intensitas kebisingan di tempat kerja dengan alat sound level meter, dan pengukuran untuk mengetahui tingkat kelelahan pada pekerja dengan alat reaction timer. Pengukuran tersebut dilakukan di dua lokasi yaitu kantor dan workshop. Kuat hubungan antar variabel dianalisis dengan menggunakan uji korelasi spearman dengan melihat nilai correlation coefficient. Hasil: Penelitian menunjukkan bahwa dari 14 orang (43,8\%) tidak mengalami kelelahan, 15 orang (46,9\%) mengalami kelelahan ringan, 2 orang (6,2\%) mengalami kelelahan sedang, dan 1 orang (3,1\%) mengalami kelelahan berat. Kelelahan paling banyak dialami oleh pekerja yang terpapar panas yaitu 18 pekerja (56,2\%) dan pekerja yang terpapar bising yaitu 15 pekerja (46,9\%). Simpulan: Terdapat hubungan yang sedang antara temperatur $(p=0,519)$ dengan kelelahan. Kebisingan $(p=0,688)$ memiliki hubungan yang kuat dengan kelelahan pada pekerja area workshop reparasi kapal di PT. X Surabaya.
\end{abstract}

Kata kunci: asupan kalori, beban kerja, industri rumahan, kelelahan kerja, pembuat makanan

Author for Correspondence:

Aulia Nur Pratiwi

Email: aulianp07@gmail.com

Telephone: +6287855772113

(C2019 IJOSH. Open access under CC BY NC-SA license doi: 10.20473/ijosh.v8i3.2019.274-283. Received July 10, 2018, received in revised form February 08, 2019, Accepted November 04, 2019, Published: December 2019 


\section{INTRODUCTION}

The development of science and technology has led to increased competition in the industrial world. As an example, companies are required to always increase their product quality and quantity by utilizing many kinds of technology, which results in the change from the use of human power into the engine that can affect the condition of the working environment.

Ministry of Manpower and Transmigration (2003) Article 86 identified that employees serve the right of protection of occupational safety and health, work morals and ethic, as well as the treatment based on human dignity and religious values. One endeavor of occupational safety and health is in the form of maintaining a decent working environment to remain safe and healthy in accordance with the determined standard of threshold values. These endeavors are carried out in order to create a working environment that causes no harm in the form of occupational deceases nor accidents; thus, the employees can be in the healthiest condition. Besides the working environment, other things that are influential to work performance are physical environment factors, such as light intensity, noise, air temperature, and vibration.

A decent working environment is a workplace where the workers can perform their works optimally, healthily, safely, and comfortably. The balance between the working environment and human power is believed to increase the productivity level. The exposure of physical environment in a workplace, such as noise, heat pressure, lighting, and vibration that are not in accordance with the standardized regulation may lead to work fatigue (Suma'mur, 2009). It has been proven that work fatigue contributes to more than $60 \%$ of the reported occupational accidents, whether it is caused by physical or mental fatigue (Setyawati, 2010). Fatigue can be defined as a body mechanism that functions as an alert when there is an imbalance inside the human body and in need of a sufficient amount of rest to be recovered (Tarwaka, 2010). The emerge of fatigue can be triggered by several factors, including internal and external factors. The internal factors that can cause fatigue comprise age, years of service, sex, nutritional status, and many other things. Meanwhile, the external factors are physical working environments, including noise, temperature, lighting, and vibration. Plenty of research has denoted that the physical environment factors in a workplace, such as noise and temperature, are some of the main triggers of work fatigue.

Working in an uncomfortable environment may generate non-optimal works, laziness, and exhaustion that can result in low work performance. For example, the workers who work under the noise exposure that exceeds the Threshold Limit Value (TLV) of $85 \mathrm{~dB}$ may not be fully productive and healthy due to the harmful environment. Moreover, the overheat working environment can also trigger the occurrence of fatigue that results in human error.

According to the research conducted by Andriani (2016), the air temperature in the workshop 9 at PT X Jakarta was around $32^{\circ} \mathrm{C}-37^{\circ} \mathrm{C}$, which results in mild fatigue which was suffered by $64.4 \%$ of the workers. Apparently, this because the temperature is not in accordance with the ideal temperature for a workplace in Indonesia, which is around $24^{\circ} \mathrm{C}-26^{\circ} \mathrm{C}$ (Suma'mur, 2014). The other research authored by Nabila (2012) regarding fatigue caused by the exposure of noise that exceeds the TLV of $100 \mathrm{~dB}$ showed that $61 \%$ of the workers in the department of melting process at Foundry Plant I at PT Komatsu Indonesia were suffered from mild fatigue.

The working environment with hot temperatures and exceeded noise can harm the workers' health. Those two factors can trigger fatigue since the workers work in an uncomfortable environment. Work fatigue affects work performance, thus, supervision and controls of the temperature and noise in a workplace are indeed necessary.

This research was carried out to the workers of the ship preparation workshop at PT X Surabaya. This workshop is responsible for repairing many kinds of the ship, such as ferry, cargo, tanker, tug boat, and container. Furthermore, the activities in this workshop comprise the floating repair, docking, re-plating, machinery and electricity repair, finishing (painting), and undocking. The workers in the north hull construction are divided into two areas; the workshop area and the outside area. In the workshop area itself, there are workers who work at the office and workshop. At the workshop, there are some works to be performed, such as marking and cutting, mold loft, and firring. The workers at PT X Surabaya start working from 07:00-12:00 UTC+7 and have a 1-hour of break time before continue working from 13:00-16:00 WIB. Generally, the works completed are plate cutting, welding, and plate connecting. These works are completed by utilizing machines, 
such as welding machines and hand grinding machines. Those machines are potentially enough to produce noise, in addition to the heat-related work that results in the hot and dry working environment, which can harm the workers' health.

Work fatigue due to lack of concentration while working, which can lead to the occurrence of occupational accidents. In fact, many occupational accidents are discovered caused by work fatigue that is mainly resulted from a lack of adaptation to uncomfortable working environments (Priyono, 2010).

The former elucidation is the main background of this research. In addition, this research aims to analyze the correlation between the physical environment factors, namely temperature and noise, and the fatigue of the workers in the ship reparation workshop at PT X Surabaya.

\section{METHODS}

This research is observational research due to the fact that it was completed by performing a direct observation of the object without giving interventions nor special treatments. Seen from the method of data analysis, this research is descriptive research. In addition, this research was carried out by implementing the cross-sectional approach, which is collecting and measuring the independent and dependent variables during a certain period of time.

This research took place at PT X Surabaya in January 2018. The primary data was obtained by measuring the temperature, noise, and work fatigue as well as conducting an observation. The respondents of this research were all 32 workers in the ship reparation workshop at PT X Surabaya. The workers at the workshop were assigned to 2 different work areas, namely the office and workshop. In the workshop area, there are 3 other divisions, such as marking and cutting, mould loft, and firring.

The dependent variable of this research is work fatigue, which was measured by the reaction timer. On the other hand, the independent variables are temperature and noise that were measured by hygrothermometer and sound level meter, respectively.

The data obtained were then analyzed to figure out the strength of the correlation between variables. The data analysis was presented in the form of crosstabulation. Whereas, to ascertain the correlation strength, the correlation coefficient value attained from the Spearman correlation test was applied.

\section{RESULTS}

\section{The Workers' Characteristics}

From a total of 32 respondents, by referring to Table 1, it can be noticed that most of them or as many as 17 people are in the age group of $>50$ years old (53.1\%). Meanwhile, seen from the years of service, there are 13 people (40.6\%) categorized in the group of 21-30 years of service. Furthermore, the nutritional status with the most workers as many as 21 people is overweight (65.6\%).

\section{Temperature}

The measurement was completed in two different areas: the office and workshop. In the workshop area, there are three other sections, namely marking and cutting, mould loft, and firring. Based on the measurement results, the temperature in the workplace is categorized into two: normal and abnormal. The normal temperature ranges from $18^{\circ} \mathrm{C}-30^{\circ} \mathrm{C}$, while the abnormal temperature spans between $<18^{\circ} \mathrm{C}$ and $>30^{\circ} \mathrm{C}$. This standard, which is $18^{\circ} \mathrm{C}-30^{\circ} \mathrm{C}$, has been established by the Ministry of Health Decree (2002) on the Standard Temperature of an Industrial Workplace.

The results of the temperature measurement in Table 2 depicted that from 4 locations where the research was conducted, 3 of them are under the abnormal temperature. In other words, the temperature at the office has tallied with the standardized temperature. Meanwhile, the temperatures at the workshop areas noticeably exceed the standardized temperature.

Table 1. The Distribution of the Characteristics of the Workers at PT X Surabaya in January 2018

\begin{tabular}{cccc}
\hline Variable & Category & Frequency & $\begin{array}{c}\text { Percentage } \\
\mathbf{( \% )}\end{array}$ \\
\hline Age & $\leq 30$ & 6 & 18.8 \\
(Years old) & $36-50$ & 9 & 28.1 \\
& $>50$ & 17 & 53.1 \\
\hline Years of & $\leq 10$ & 6 & 28.8 \\
Service & $11-20$ & 1 & 3.2 \\
(Years) & $21-30$ & 13 & 40.6 \\
& $>30$ & 12 & 37.5 \\
\hline Nutritional & Underweight & 1 & 3.1 \\
Status & Normal & 10 & 31.3 \\
& Overweight & 21 & 65.6 \\
\hline
\end{tabular}




\section{Noise}

Noise intensity in a workplace was measured by the sound level meter. In this research, the noise measurement was carried out at the office and ship reparation workshop areas, wherein the workshop area, there are three more sections: marking and cutting, mould loft, and firring. Based on the results of the measurements, the noise can be divided into 2 categories, namely $<\mathrm{TLV}$, that is when the noise intensity is $<85 \mathrm{~dB}$ during an 8-hour exposure per day and $>T L V$, which is a condition when the noise intensity is $>85 \mathrm{~dB}$ during an 8 -hour exposure per day. This measurement is based on the Ministry of Manpower and Transmigration (2011) on Threshold Limit Value (TLV) of Physical and Chemical Factors in a Workplace, which established that the TLV of noise exposure is $85 \mathrm{~dB}$ of maximum 8 hours of exposure per day.

The results of the measurement displayed in Table 3 show that out of 4 measurement locations, there are 2 locations with exceeded noise. In other words, the noise in the office does not exceed the TLV, while the noises in two areas of the workshop (66.7\%) exceed the TLV.

\section{Work Fatigue}

The work fatigue or fatigue in this research is measured by utilizing a reaction timer. After that, the measurement results are grouped into four different levels of fatigue; normal, mild, moderate,

Table 2. The Results of the Temperature Measurement at PT X Surabaya in January 2018

\begin{tabular}{ccc}
\hline Location & $\begin{array}{c}\text { Measurement Result } \\
\left({ }^{\circ} \mathbf{C}\right)\end{array}$ & Status \\
\hline Office & 26.7 & Normal \\
Marking and cutting & 31.7 & Abnormal \\
Mouldloft & 31.9 & Abnormal \\
Firring & 33.2 & Abnormal \\
\hline
\end{tabular}

Table 3. The Results of the Noise Measurement at PT. X Surabaya on January 2018

\begin{tabular}{ccc}
\hline Location & $\begin{array}{c}\text { Measurement } \\
\text { Result (dB) }\end{array}$ & Status \\
\hline Office & 64.3 & $<\mathrm{TLV}$ \\
Marking and cutting & 87.8 & $\geq \mathrm{TLV}$ \\
Mould loft & 80.9 & $<\mathrm{TLV}$ \\
Firring & 90.4 & $\geq$ TLV \\
\hline
\end{tabular}

and severe. Additionally, the results of work fatigue measurement can be seen in Table 4 .

The results of work fatigue suffered by the workers were varied. Referring to Table 5 , it can be disclosed that most of the workers, as many as 15 people (46.9\%), undergo mild fatigue.

\section{The Correlation between Temperature and Work Fatigue}

An analysis regarding the strength of the correlation between variables by scrutinizing the correlation coefficient value obtained from the

Table 4. The Results of the Work Fatigue Measurement at PT X Surabaya in January 2018

\begin{tabular}{|c|c|c|}
\hline Respondent & Result (Average) & Category \\
\hline 1 & 315.3 & Mild \\
\hline 2 & 219.4 & Normal \\
\hline 3 & 186.2 & Normal \\
\hline 4 & 213.3 & Normal \\
\hline 5 & 155.3 & Normal \\
\hline 6 & 161.9 & Normal \\
\hline 7 & 298.4 & Normal \\
\hline 8 & 177.7 & Normal \\
\hline 9 & 286.4 & Mild \\
\hline 10 & 177.7 & Normal \\
\hline 11 & 319.8 & Mild \\
\hline 12 & 244.7 & Mild \\
\hline 13 & 422.7 & Moderate \\
\hline 14 & 330.8 & Mild \\
\hline 15 & 170.7 & Normal \\
\hline 16 & 320.0 & Mild \\
\hline 17 & 191.6 & Normal \\
\hline 18 & 256.2 & Mild \\
\hline 19 & 268.2 & Mild \\
\hline 20 & 230.0 & Normal \\
\hline 21 & 393.1 & Mild \\
\hline 22 & 272.7 & Mild \\
\hline 23 & 337.9 & Mild \\
\hline 24 & 704.4 & Severe \\
\hline 25 & 363.4 & Mild \\
\hline 26 & 432.7 & Moderate \\
\hline 27 & 190.0 & Normal \\
\hline 28 & 195.2 & Normal \\
\hline 29 & 180.6 & Normal \\
\hline 30 & 179.0 & Normal \\
\hline 31 & 279.6 & Mild \\
\hline 32 & 247.0 & Mild \\
\hline
\end{tabular}


Table 5. The Distribution of Work Fatigue at PT X Surabaya in January 2018

\begin{tabular}{ccc}
\hline $\begin{array}{c}\text { Work Fatigue } \\
\text { Level }\end{array}$ & $\begin{array}{c}\text { Frequency } \\
\text { (People) }\end{array}$ & Percentage (\%) \\
\hline Normal & 14 & $43.8 \%$ \\
Mild & 15 & $46.9 \%$ \\
Moderate & 2 & $6.2 \%$ \\
Severe & 1 & $3.1 \%$ \\
\hline Total & 32 & $100 \%$ \\
\hline
\end{tabular}

Table 6. The Correlation between Temperature and Work Fatigue at PT X Surabaya in January 2018

\begin{tabular}{ccccccc}
\hline \multirow{2}{*}{$\begin{array}{c}\text { Work } \\
\text { Fatigue }\end{array}$} & \multicolumn{3}{c}{ Nemperature } & \multicolumn{2}{c}{ Total } \\
\cline { 2 - 6 } & $\mathbf{n}$ & $\mathbf{\%}$ & $\mathbf{n}$ & $\mathbf{\%}$ & $\mathbf{N}$ & $\mathbf{\%}$ \\
\hline Normal & 6 & 18.8 & 8 & 25 & 14 & 43.8 \\
Mild & 0 & 0 & 15 & 46.9 & 15 & 46,9 \\
Moderate & 0 & 0 & 2 & 6.2 & 2 & 6.2 \\
Severe & 0 & 0 & 1 & 3.1 & 1 & 3.1 \\
\hline
\end{tabular}

Spearman correlation test was carried out after the measurements of temperature and work fatigue had been completed. In results, the data are presented in the form of cross-tabulation as displayed in Table 6.

Table 6 revealed that the workers with normal condition or do not suffer from fatigue mostly work under normal temperature, which is as many as 6 people (18.8\%). In addition, the workers who work under abnormal temperatures tend to undergo mild fatigue (15 people or $46.9 \%$ ), moderate fatigue ( 2 people or $6.2 \%$ ), and severe fatigue (1 person or $3.1 \%)$. The results of the Spearman correlation test showed a number of 0.519 as the correlation coefficient value, which means that the temperature has a moderate correlation with work fatigue.

\section{The Correlation between Noise and Work Fatigue}

According to the measurement of noise intensity and fatigue suffered by the workers, the analysis to determine the correlation between variables by examining the correlation coefficient value from the Spearman correlation test was completed. The data is presented in Table 7 in the form of crosstabulation.
Table 7. The Correlation between Noise and Work Fatigue at PT X Surabaya in January 2018

\begin{tabular}{ccccccc}
\hline \multirow{2}{*}{$\begin{array}{c}\text { Work } \\
\text { Fatigue }\end{array}$} & \multicolumn{4}{c}{ Noise } & \multicolumn{2}{c}{ Total } \\
\cline { 2 - 6 } & \multicolumn{2}{c}{$<\mathbf{T L V}$} & \multicolumn{2}{c}{$\geq \mathbf{T L V}$} & \multicolumn{2}{c}{} \\
\hline Normal & 12 & 37.6 & 2 & 6.2 & 14 & 43.8 \\
Mild & 3 & 9.3 & 12 & 37.6 & 15 & 46.9 \\
Moderate & 0 & 0 & 2 & 6.2 & 2 & 6.2 \\
Severe & 0 & 0 & 1 & 3.1 & 1 & 3.1 \\
\hline
\end{tabular}

Table 7 denoted that the workers who work under normal noise intensity (12 people or $37.6 \%$ ) tend to have a normal condition or do not undergo any kind of fatigue. However, mild, moderate, and severe fatigues are noticeably suffered by the workers who work under the environment in which noise exceeds the TLV, for instance: 12 people or $37.6 \%, 2$ people or $6.3 \%$, and 1 person or $3.1 \%$, respectively. Additionally, the results of the Spearman correlation test displayed a number of 0.688 , which indicated that there is a strong correlation between noise and work fatigue suffered by the workers.

\section{DISCUSSION}

\section{Temperature}

The temperature measurement was carried out at four points in two different locations, that is the office and three division areas of the workshop (marking and cutting, mould loft, and firring). The standard referred by this research is the Ministry of Health Decree (2002) on the Standard Temperature of an Industrial Workplace, which is $18^{\circ} \mathrm{C}-30^{\circ} \mathrm{C}$. As a result, it was obtained that out of four measurement points, the temperature in the office is the only temperature in accordance with the standardized temperature, which is $26.7^{\circ} \mathrm{C}$. Moreover, this result was due to the provision of fans and ventilation to manage temperature stability.

In addition, the three other measurement points that are located in the workshop area have exceeded the standardized temperature. Apparently, this because the workshop area is a semi-outdoor area and is located near the sea where the heat-related works done which can increase the temperature level, especially the one inside the room. 
According to Suma'mur (2014), in a high and humid temperature, the higher the velocity of the airflow, the more pressure the workers encounter. Additionally, high temperature can reduce agility; extend reaction and decision-making time; interfere with the thinking accuracy; and disrupt the sensory and motor nerve coordination (Suma'mur, 2009). As the consequences, work fatigue, the decrease in productivity, and the occurrence of occupational accidents due to negligence may happen in a workplace with an overheat temperature.

\section{Noise}

The noise measurement was completed at four points in two different locations, that is the office and three division areas of the workshop (marking and cutting, mould loft, and firring). The Ministry of Manpower and Transmigration (2011) on Threshold Limit Value (TLV) of Physical Factors and Chemical Factors in a Workplace established that the TLV of noise exposure is $85 \mathrm{~dB}$ of maximum 8 hours of exposure per day.

From the measurement, it can be noticed that out of 4 locations, 2 of those are under the noise that exceeds the TLV, while the other 2 are not. The locations in which noise exceeds the TLV are the area of marking and cutting, with the noise of $87.4 \mathrm{~dB}$ that is mainly caused by the Genset behind the working area, and the area of firring with the noise of $90.4 \mathrm{~dB}$, which noise comes from the hand grinding machine. In other words, the noises in those areas are not complying with the standardized TVL, inasmuch as the noises exceed $85 \mathrm{~dB}$. Besides, the noise exposure received by the workers is worsened by the absence of the personal protective equipment, for instance, earplug or earmuff to reduce the intensity of noise. Furthermore, it was explained that noise may result in sleep or communication disorder. As a consequence, if the workers keep being exposed to such noise, body physiological disorders that affect the health (Suma'mur, 2014).

\section{Work Fatigue}

Fatigue is a common complaint indicated by the decrease in work performance, motivation, as well as physical and mental activities (Lusiana, Zahroh and Baju, 2014). The work fatigue measurement was performed to 32 workers, which consisted of 5 workers from the office area and 27 workers from the workshop area. As a result, it can be denoted that in the workshop area, there are 14 people (43.7\%) who are healthy, 15 people $(46.9 \%)$ suffer from mild fatigue, 2 people $(6.3 \%)$ undergo moderate fatigue, and 1 person (3.1\%) suffers from severe fatigue. In other words, the workers in the workshop area, particularly at marking and cutting sections, are noticed suffering from fatigue due to the fact that both the temperature and noise in this area reportedly exceed the TLV.

Referring to Tarwaka, Bakri and Sudiajeng (2004), work fatigue can be triggered by various factors, and one of them is the physical environment conditions in the workplace. Thus, in order to maintain the health and welfare of the workers, the stability and the safety of the physical environment conditions must be highly controlled.

When this research was being carried out, there were 8 ships with different levels of damage being repaired and must be perfected in the adjacent time. Consequently, the workers in the ship reparation workshop area suffered from fatigue since they had to work fast, so the ships could be repaired on time. Not only that, but the fatigue was also caused by the hot and noisy working environment, which indeed, those kinds of the environment become an additional workload for the workers.

It has been confirmed that work fatigue can result in a decrease in work motivation, work passion, thinking ability, alertness, and the Regrettably, most workers do not really pay attention to fatigue symptoms since they lack knowledge regarding work fatigue. As a result, they do not know how to prevent themselves from experiencing fatigue and when they suffer from it, they are clueless about how to recover. According to Tarwaka (2015), work fatigue can be prevented by redesigning proper working environment, consuming enough and balance calories, and taking at least a 1-hour break during the working period.

\section{The Correlation between Temperature and Work Fatigue}

The temperature measurement in all of the locations indicated that the workshop area is the area with the highest temperature. Previously, it has been asserted that temperature is correlated with the emergence of work fatigue. In fact, based on the research, the workers who work under the temperature of $18^{\circ} \mathrm{C}-30^{\circ} \mathrm{C}$, which is as many as 18 people (56.2\%), suffered from fatigue. Evidently, the hot environment in the ship reparation workshop area is due to its location which is near the sea and perceived as a semi-outdoor area. Furthermore, heat- 
related works performed by the workers contribute to the increase in the temperature.

According to The Industrial Hygiene Occupational Safety and Health Association (2011), an overheat temperature can cause an increase in heart rate, body temperature, and sweat production. In addition, the increase in blood pressure results in the more intense work of the heart. Consequently, when the heart can no longer pump the blood all over the body, some of the blood will accumulate in the legs and lungs tissues. Accordingly, the blood accumulated in the lung tissues will cause breathing problems providing that the amount of the oxygen needed is not sufficient. As a result, the limited oxygen will be one of the triggers of fatigue caused by the accretion of lactic acid (Pramono, 2008).

Furthermore, working under an overheat temperature can be an additional workload for the workers. Referring to the research conducted by Umyati and Andara (2017), it was obtained that the pulpit VIII and IX operators at PT Krakatau Wajatama who work under the temperature of more than $26^{\circ} \mathrm{C}$, or $77.8 \%$, suffer from work fatigue.

Another research authored by Kumalasari, Ana Achmala Nur., Rachman F. (2017), proved that there is a significant correlation between temperature and fatigue. In her research, she discovered that the workers at the packaging section at a cooking oil and margarine company suffer from fatigue due to the fact that they have been working under a temperature of $35^{\circ} \mathrm{C}$.

In broad, it is proposed that the higher the temperature in the workplace, the more sweat produced by the workers, which in consequence, the workers will get dehydrated more easily. Moreover, when a worker undergoes dehydration, she/he will get tired and suffer from fatigue more easily (Suma'mur, 2009).

However, there are several endeavors that can be carried out to prevent the occurrence of work fatigue. One of those is by installing ventilation in the workplace. By referring to Indonesian National Standard (2001), installing ventilation can reduce excessive heat since ventilations flow fresh air from the outside to replace the hot air in the workplace. In addition, there are two kinds of ventilation that can be considered to install, namely natural and mechanic ventilation. Besides, according to The National Institute for Occupational Safety and Health (2011), workers are recommended to drink a minimum of a glass of water $(150-200 \mathrm{cc})$ once every 15-20 minutes to replace the body fluids that are excreted through sweat to prevent dehydration.

\section{The Correlation between Noise and Work Fatigue}

Noise can be described as an unwanted disturbing sound that can trigger the occurrence of fatigue (Tarwaka, 2010). The measurement results displayed that noise has a strong correlation with fatigue. The noise sources in the office area are in the form of fans and working activities in which noise intensity is still under the TLV. However, in the workshop area which noise exceeds the TLV, the sources are from the equipment used to complete the work, for instance, a Genset, aside from the activities of the workers itself.

At the marking and cutting section in the workshop area, it was reported that the noise intensity exceeds the TLV due to the fact that this section is located precisely next to the Genset. In the second section in the workshop area, mould loft section, it was noticed that the noise intensity is still under the TLV, providing that the section is located near the office area. The third section in the workshop area is firring section. In this section, undoubtedly, the noise intensity is reported as the highest intensity among the other locations. Apparently, this because the activity performed in this section is steel cutting that utilizes hand grinding machines.

As proposed by Tarwaka (2010), the stress caused by noise exposure in a workplace may initiate the rate of early fatigue, anxiety, and depression. Moreover, noise can also cause body physiological disorders on autonomic nerves, indicated by the increase in muscle tension that results in the emergence of fatigue more quickly (Setiarto, 2002).

The results of this research are in line with the results of the research piloted by Lestari (2016), which concluded that noise indeed correlated to fatigue suffered by the workers at the boiler unit 1 at PJB Tanjung Awar-Awar. Nevertheless, even though noise can be one of the most influential factors in the increase of work fatigue, it is not the main factor that causes work fatigue. In fact, work fatigue might arise due to cumulative activities or work conditions that make the workers suffer from fatigue, before and during this research was conducted. As for another point of view, the research completed by Makalalag, Kalesaran and Kawatu (2017) noticed that out of 
24 people who are exposed to the noise intensity of $>85 \mathrm{~dB}, 21$ suffer from moderate fatigue. To add more, based on the research done by Romdhoni and Brahmadi (2015), it was obtained that noise is not correlated with fatigue suffered by the workers at PT Coronet Crown Purwokerto Banyumas. At that site, it was confirmed that noise triggers a cognitive disorder in a form of anxiety. In the meantime, anxiety can interfere with the metabolism process of the body that results in the buildup of lactic acid in the muscle and lactic acid accumulation is one cause of fatigue (Rosanti, 2011).

Fatigue may result in a decrease in muscle strength due to the accumulation of metabolic waste substances and lactic acid. Nonetheless, one of several endeavors that can be performed in order to prevent noise to interfere the body metabolism is to maintain the noise exposure, so it does not exceed the TLV. Another endeavor is by controlling the time limit and noise exposure through providing personal protective equipment, for example, earmuff or earplug. The wearing of personal protective equipment can be adjusted depending on the needs of each worker and the attained exposure.

\section{CONCLUSION}

More than half of the workers in the ship reparation workshop (53.1\%) are categorized in the age group of $>50$ years old with 21-30 years of service $(40.6 \%)$ and overweight nutritional status $(65.6 \%)$. The temperature measurement in the office area is in accordance with the standard determined by the Ministry of Health Decree (2002) on the Standard Temperature of an Industrial Workplace, which is $18^{\circ} \mathrm{C}-30^{\circ} \mathrm{C}$, while the temperatures at three divisions of the workshop area are noticed exceeding the standardized temperature. Furthermore, the noise in the office area does not exceed the TLV, whereas, in the workshop area, there are two divisions which noise exceed the standard determined in the Ministry of Manpower and Transmigration (2011) on Threshold Limit Value (TLV) of Physical Factors and Chemical Factors in a Workplace.

From the results of the measurement, it can be perceived that the level of fatigue which is mostly undergone by the workers is mild fatigue, with the sufferers as many as 15 people $(46.9 \%)$. Therefore, it can be concluded that there is a moderate correlation between temperature and fatigue in this research. On the other hand, there is a strong correlation between noise and fatigue experienced by the workers in the ship reparation workshop at PT X Surabaya.

\section{ACKNOWLEDGMENT}

The authors especially praise the Almighty God for His guidance in finishing this research. Additionally, the authors are also grateful for the supervisors who always gave insightful opinions about this research. Besides, the authors are thankful for the respondents and the company for participating in this research.

\section{REFERENCES}

Andriani, K. W. (2016) 'Hubungan Umur, Temperatur, dan Kebisingan dengan Kelelahan Subjektif Individu di PT. X Jakarta', The Indonesian Journal of Occupational Safety and Health, 5(2), pp. 112-120.

Indonesian National Standard (2001) 'Tata cara

Perancangan Sistem Ventilasi dan Pengkondisian Udara pada Bangunan Gedung'. Jakarta: National Standardization.

Kumalasari, Ana Achmala Nur., Rachman F., W. (2017) 'Analisis Pengaruh Karakteristik Individu dan Lingkungan Kerja Terhadap Kelelahan pada Pekerjaan di Perusahaan Minyak Goreng dan Margarin', in Proceeding 1stConference on Safety Engineering and Its Application, pp. 13-18.

Lestari, D. P. (2016) Hubungan Faktor Lingkungan

Kerja dengan Kelelahan Kerja Pada Pekerja Unit 1 Boiler PJB Tanjung Awar-Awar. Undergraduate Thesis. Surabaya: Faculty of Public Health, Universitas Airlangga.

Lusiana, D., Zahroh, S. and Baju, S. (2014)

'Penyebab Kelelahan Kerja pada Pekerja Mebel', Kesmas Jurnal Kesehatan Masyarakat Nasional, 8(8), pp. 386-392.

Makalalag, R. N. A., Kalesaran, A. F. . and Kawatu, P. A. . (2017) 'Hubungan antara Intensitas Kebisingan dengan Kelelahan Kerja pada Tenaga Kerja Ground Handling PT. Gapura Angkas Bandar Udara Internasional Sam Ratulangi Kota Manado', Journal Community Health, 9(3), pp. 69-74.

Ministry of Health Decree (2002) Number 1405/ MENKES/SK/XI/2002 Concerning Persyaratan Kesehatan Lingkungan Kerja Perkantoran dan Industri. Jakarta: Ministry of Health. 
Ministry of Manpower and Transmigration (2003) Undang-undang Republik Indonesia No. 13 Tahun 2003 tentang Ketenagakerjaan. Jakarta: Ministry of Manpower and Transmigration.

Ministry of Manpower and Transmigration (2011) Regulation Number 13 of 2011 on Threshold Limit Value of Physical Factors and Chemical Factors in a Workplace. Jakarta: Ministry of Manpower and Transmigration.

Nabila, S. (2012) Hubungan Intensitas Kebisingan dengan Kelelahan Kerja Pada Tenaga Kerja Melting di Foundry Plant 1 PT. Komatsu Indonesia Jakarta. Undergraduate Thesis. Surakarta: Faculty of Medicine, Universitas Sebelas Maret.

Pramono, S. W. (2008) Faktor-Faktor yang Berhubungan dengan Kelelahan Pada Pekerja di Bagian Saw Mill PT Marcelindo Jaya Pratama Desa Kuripan Kecamatan Karangawen Tahun 2008. Undergraduate Thesis. Semarang: Faculty of Public Health, Universitas Muhammadiyah Semaran.

Priyono, D. (2010) Iklim Kerja dan Kelelahan Subyektif pada Pekerja Proyek Relokasi Jalan Arteri Porong-Siring 1 Paket 3 Sidoarjo. Undergraduate Thesis. Surabaya: Faculty of Public Health, Universitas Airlangga.

Romdhoni, M. F. and Brahmadi, A. (2015) 'Hubungan antara Status Gizi dan Kebisingan terhadap Kelelahan Karyawan di PT. Coronet Crown Purwokerto Banyumas', Ilmiah Ilmu-ilmu Kesehatan, 13(3), pp. 29-36.

Rosanti, E. (2011) Perbedaan Tingkat Kelelahan Kerja pada Tenaga Kerja Wanita Antara Shift Pagi, Shift Siang, dan Shift Malam di Bagian Winding PT. Iskandar Indah Printing Textile Surakarta. Undergraduate Thesis. Surakarta: Faculty of Medicine, Universitas Sebelas Maret.
Setiarto, H.(2002)Beberapa Faktoryang Berhubungan dengan Kelelahan pada Pengemudi Bus Jurusan Grabag-Borobudur. Undergraduate Thesis. Semarang: Faculty of Public Health, Universitas Diponegoro.

Setyawati, L. (2010) Selintas Tentang Kelelahan Kerja. Yogyakarta: Amara Books.

Suma'mur, P. K. (2009) Higiene Perusahaan dan Kesehatan Kerja (HIPERKES). Jakarta: Sagung Seto.

Suma'mur, P. K. (2014) Higiene Perusahaan dan Kesehatan Kerja (HIPERKES). 2nd edn. Jakarta: Sagung Seto.

Tarwaka (2010) Ergonomi Industri. Surakarta: Harapan Press.

Tarwaka (2015) Ergonomi Industri: Dasar-Dasar Pengetahuan Ergonomi dan Aplikasi di Tempat Kerja. Surakarta: Harapan Press.

Tarwaka, Bakri, S. and Sudiajeng, L. (2004) Ergonomi untuk Keselamatan, Kesehatan Kerja dan Produktivitas. Surakarta: Uniba Press.

The Industrial Hygiene Occupational Safety and Health Association (2011) 'Praktikum Laboratorium Hiperkes Bagi Mahasiswa'. Yogyakarta: Municipal Representative of Manpower and Transmigration of the Province of Special Region of Yogyakarta.

The National Institute for Occupational Safety and Health (2011) 'Protecting Workers from Heat Illness'. Washington D.C: The National Institute for Occupational Safety and Health.

Umyati, A. and Andara, S. A. (2017) 'Identifikasi Lingkungan Fisik dan Penilaian Kelelahan pada Operator Pulpit VIII Dan IX di PT. Krakatau Wajatama', Journal Industrial Servicess, 3(1), pp. 301-304. 